\title{
COVID-19 Impact On Stock Market and Economy of India
}

\author{
Supratik Sarkar* \\ Student, Department of Management, Symbiosis Centre for Management Studies, Pune, India \\ *Corresponding author: supratik.sarkar@associate.scmspune.ac.in
}

\begin{abstract}
Background: The current coronavirus (SARS-COV2/ Covid-19) pandemic has wreaked havoc on the global economy and India has been hit significantly in every sector from banking and tourism to infrastructure development and rural-urban consumption.

Objectives: To snapshot a broad market view of stocks, mutual funds, FDI and the general economy of India during the current Covid-19 pandemic.

Methodology: Secondary data research using google scholar, Open Athens, government and United Nations reports and online verified news outlets.

Findings: The current pandemic has led the market to crash however immediate necessary fiscal implementations of major economies have ensured the markets have also seen one of the fastest recoveries and thus we are presented with a unique opportunity to make the right choices and consolidate the market and economy in such a way that this recovery is sustained on a strong foundation rather than short-term market sentiment.
\end{abstract}

Keywords: Coronavirus, COVID-19, Economy, GDP, Pandemic, Stock market.

\section{Introduction}

Coronavirus disease (COVID-19) is an infectious disease first identified in December 2019 in Wuhan, Hubei, China on 17 November 2019, and has resulted in the current global crisis. Since then it's spread has resulted in high stock-price volatility, decreases in nominal interest rates, and likely contractions of real economic activities due to uncertainty about how it will affect the economy and for how long, across the globe.

As of 30 September 2020, more than 34.1 million cases have been reported across the world, resulting in more than 1 million deaths. More than 25.1 million people have recovered. As a pandemic, it is causing grave economic and human distress.

However, in India, the first case was reported in Kerala on 30th January 2020. For the current short-term trend, it has translated into extreme volatility in the financial markets and aligns with previous market studies showing economic uncertainty can increase volatility in financial market returns. [9], [12].

Today's hyper-globalized economies mean that even if India didn't become the 3rd largest hotspot for confirmed coronavirus cases, it'd still be severely affected by other epidemic struck countries with which it has strong trade relationships with.

ANZ Research economists stated that around $14 \%$ of India's imports come from China, making it the nation's biggest import partner. India imports electrical machinery, cell phones, heavy machinery, telecom and pharma ingredients, fertilizer, food, and textiles, etc. from China. This is majorly due to cheap supply from economies of scale resulting in higher margins for dealers and retailers even after import tariffs. India imported $\$ 62.4$ billion worth goods from China from April 19' to February 20. All the while China contributing to just 5.1 percent of India's total exports in FY-2019, on account of importing chemicals and fuels from India [15].

To start with the loan book of India even before the crisis hit, according to Nikkei data as of February 2020, the Indian telecom sector is the most financially at risk, with an estimated $\$ 30$ billion worth of bad loans, followed by steel and infrastructure ( $\sim 15$ billion each), energy ( $\$ 12$ billion), and textiles ( $\sim 10$ billion). Non-performing loans have risen more than 5 percentage points to amount to a staggering $8.9 \%$ of overall bank lending in India, in just the last five years. This is the largest increase among the group of the world's 20 major economies, according to the International Monetary Fund. [20]. This poses a large threat for the future of bad loans in lending and how they will be restructured to reduce the effect on economy.

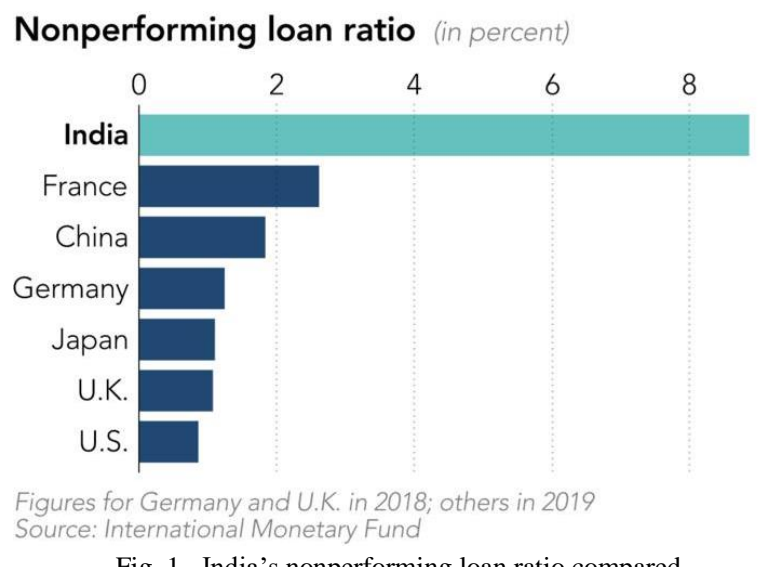

Fig. 1. India's nonperforming loan ratio compared

As with similar economies around the world, COVID-19 poses a grave uncertainty about India's economy in both the short and long term. 


\section{Potentially bad loans held by India's listed companies by sector (in billions of dollars)}

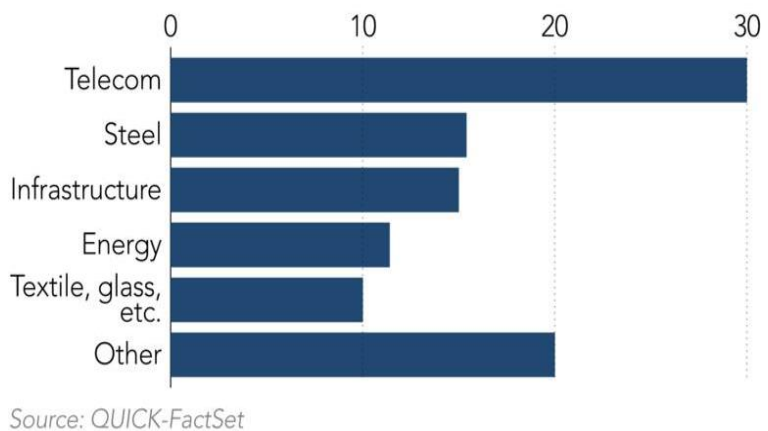

Fig. 2. India's potentially bad loans by sector

\section{Review of Literature}

On broad market sentiments, a few observations came up studying both the past economic growth of India and current market reactions.

Akriti Gupta on studying Indian FDI from 2000-2019 found foreign institutional investments have shown an increasing trend in Indian stock market for the last 2 decades. This is due to strong fundamentals in the domestic economy and an overall positive global investor sentiment. However, in long term domestic market fundamentals and inflows from foreign institutional investors will probably be strongly influenced from the development in the global market as a whole accounting for global trade relations and valuations as such. [1]

Expanding on the same successes it was discussed that on studying past growth cycles in India, post-Covid-19 macrofinancial packages and policy reforms are an opportunity to trigger another such cycle, by raising inclination of the average Indian to spend more whilst maintaining healthy financially responsible savings as a percentage of their net worth. It was also mentioned that the current crisis calls for a large macroeconomic stimulus [16]. Dr. Kishore Kumar Das studied how the coronavirus pandemic COVID-19 could lead to a slowdown in domestic demand. This has proven to be true as we have seen a severe erosion of purchasing power due to pay cuts, job losses and the slow-down effect of deferred demand all combining to form a long-lasting impact on different sectors. This impact is expected to be especially pronounced where the demand is discretionary in nature. [11]

Another report [24] inferred that the economic gap would be increased after this pandemic disease. Similarly, the reduction of middle-class investors in stock markets would increase the chance of control in the limited hands of higher net worth investors. Christopher Wood believes the current pressing risk in Indian financials is the asset qualities in banking, which have historically been deeply invested in developer and housing finance company space as a result of the NBFC lending squeeze. The current risk is consumer lending space and higher retail defaults [27].

Independent economic reports [6] estimate growth declining to 2.5 per cent in 2020, and 3.5 per cent in FY20-21 eventually leading to a loss in excess of $\$ 120$ billion from global and domestic trade revenues. This is a huge cause for concern.

Even connecting the fall in the market with the demonetization-GST fall of 2018, Alok Kumar Mishra [3] in his study found that the stock returns of all the indices turned out to be negative during COVID-19, which was unlike the scenario even during the post-demonetization and the post-GST phase in Indian stock market. The volatility of the benchmark was 2.77 during the study as compared to 0.51 in post demonetization and 0.59 post GST phases, respectively. He suggests RBI intervention in forward contracts policy and trade floor-ceilings on commercial banks and NBFCs to arrest the speculative fall of rupee against the dollar. This was actually implemented in July and has led to positive results in stabilizing rupee.

On the note of the credit growth success story of India, [22] analyzed how Credit growth declined sharply despite the RBI lowering the policy repo rate by 135 basis points to $5.15 \%$ back in 2019, which was the lowest policy rate in nearly a decade. While it probably could have been due to lack of demand given the balance sheet crisis in the private corporate sector, actual market study with banks suggests that reluctance in banks to extend credit due to pre-existing high default rates in commercial banking has been a major factor. Amidst a slowdown in the economy, bank credit was expected to grow at 6.5-7.0\% during the current fiscal ending March'20, according to rating firm ICRA, NSE at $-1.99 \%$. This was the lowest growth recorded since the last 58 years.

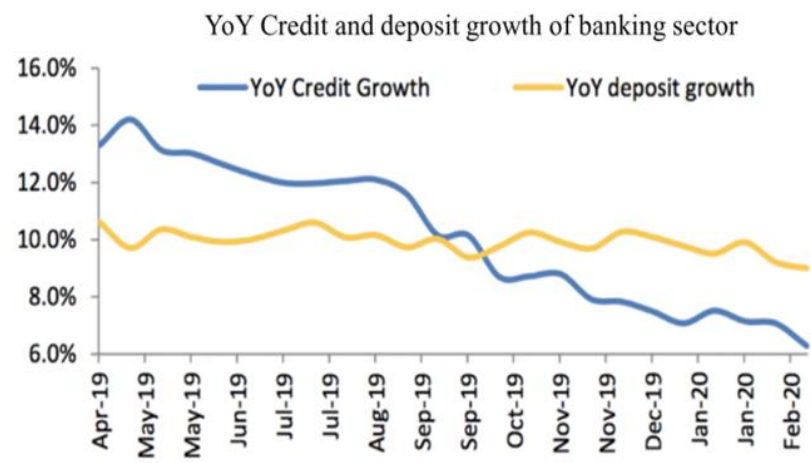

Fig. 3. India's Credit and Deposit growth in banking for 2019-2020 FY Source: [1]

(FIIs) have been steady investors in Indian debt over the last five years due to arbitrage opportunities between international interest rates and Indian rates alongside a generally stable currency. As the Covid-19 pandemic began spreading across countries and specially affected the US, growing risk aversion and flight to safety led these investors to sell large volumes of Indian debt paper, in addition to stocks (figure 4). Overall, FPI outflows were to the tune of $\$ 7.1$ billion in 2019-20 (up to March 31, 2020). In addition to this, March is generally tight liquidity period in India since advance tax payments, financial year ending etc. result in greater demand for cash during this period. 


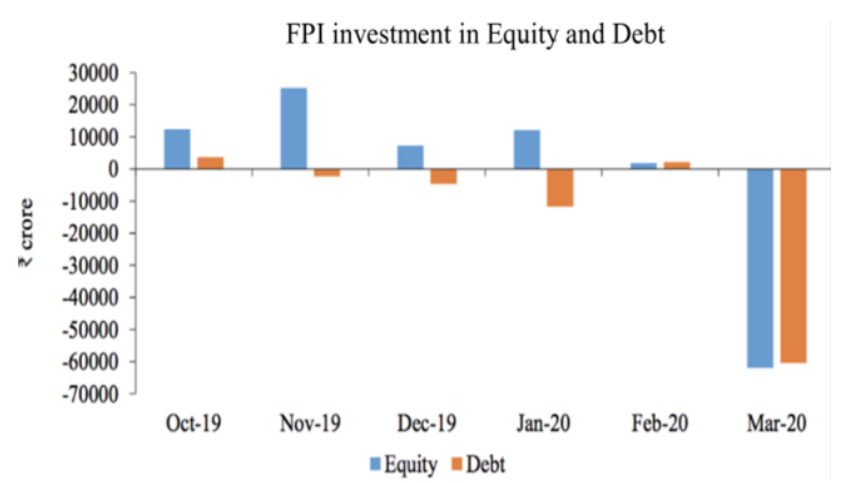

Fig. 4. India's FPI compared for Equity vs. Debt (Source: [1])

For global stock markets, China and USA studies were considered for the literature review. Research found that the due to daily growth in total confirmed cases and total cases of death caused by COVID-19, markets saw significant negative effects on Chinese stock prices and portfolio returns across all companies. [2]

Bowes in his paper concluded conditional variance in S\&P 500 returns increase when presidential election futures market asset prices indicate greater uncertainty about the outcome of an upcoming election. This was generalized in his paper as economic uncertainty translates into higher volatility in stock market returns. [9]

Another research concluded stock market returns declined as the number of confirmed cases increased and much more proactively to the growth in the number of confirmed cases as compared to the growth in the number of deaths. A stronger negative market reaction during early days of confirmed cases than 60 days after the initial confirmed cases was also observed [5]. This was aligned with other studies of similar research [9] on how economic uncertainty leads to high volatility. The only study that couldn't support these findings were from one paper that studied how rapid increase in infection rate worldwide had negative repercussions on financial, commodity markets and economy. The analysis revealed that there is no significant negative impact on the Indian stock market. Also, the impact is for short-run, however, the long-term impact could be contrary. Even short-term, this contradicts other research [3], [8], [9], [21] one of which concluded increased search queries for COVID-19 not only have a direct effect on implied volatility but also have an indirect effect via stock returns highlighting a risk-aversion wave operating over pandemic conditions. There is a positive direct relationship between Google trend metrics for COVID-19 and stock market implied volatility, leads to elevated risk-aversion in stock markets. But this contradicted [9] wherein data from 20th January to end of May 2020 stated that there were no significant differences in the relationship between stock return and changes on daily cases and deaths across the different industries, clearly being an outlier as a study.

Bloomberg [8] reported NSE Nifty 50 Index member's profits fell $\sim 15 \%$ last quarter $\mathrm{v} / \mathrm{s} 2019$. This was the worst drop since 2014 with the communications, energy and industrials sectors recording the steepest declines. Dr. Manish Sharma [12] concluded Media, Realty, Hospitality, Service sectors and Manufacturing have been hit the hardest in the current market slump. Another research [10] found highly impacted sectors include automobiles (was already in a slowdown), metal industry, PSU, realty, industry and capital goods industries. From the prediction it can be seen that the Indian market would continue to see heightened and fresh volatility for coming few months). The measure of volatility seems high in case of finance.

In the end, it can be concluded that if the predicted volatility stays at such a high level, it can bring an even steeper fall in the market due to domino effects of volatility.

Independent market expert Sabharwal, [23] believes a correction in consumer stocks can be a good entry point for investors. Sabharwal believes if the US stimulus story fades, growth in IT could slow down, something that has already started as of July 2020. He warns of higher retail NPAs in the coming periods that spell bad phase for bank stocks and believes investment goals for all kinds of investors in equity should be to consistently beat the market by just 3-5\% which translates to outperforming $99 \%$ fund managers.

Research [17] found Sectors like Automobile and Nifty 50 have been hit worst due to this outbreak whereas panic shopping and government funding has given a boost to returns of FMCG, Pharma, Metals, etc. Due to the constant pressure on a vaccination rush, pharma stocks have been getting unprecedented trade licenses and medicine approvals. Another study [4] signifies pharmaceutical stocks maintaining a general momentum compared to Nifty. Also, when COVID-19 hits its worst in China, it pulls back the profit margin of the Indian pharmaceutical industry because Indian pharmaceutical companies are greatly dependent on Chinese base pharmaceutical ingredients called active pharmaceutical ingredient (API). Coupled with break-in supply chain has resulted in the scarcity of essential components required for pharmaceutical manufacturing.

On studying strategic business adaptations of Indian companies to battle the lockdown, ground research found most FMCG companies forged swift tie-ups with delivery companies such as 'Zomato' and 'Swiggy' to shift into digital retail. [26]

This period also saw a massive rise in popularity of apps like 'Dunzo' which act as aggregators-delivery solutions for groceries. This suggests due to lockdown a significant consumer base now just wants to order from the safety of their home and contactless-deliveries of their purchases.

Rural consumption-driven growth was attributed to massive reverse migration in lieu of job cuts, a good monsoon making agriculture more profitable and increased government expenditure through public projects which are likely to ensure increased demand from rural India.

Rural consumption has been historically been a dawdler during the quarters preceding the pandemic but has thankfully shot up as of September 2020 probably due to pent up demand 
and disruptions in existing supply-chains.

For the mutual fund industry, the following observations were found by Dr. Rao [13]

1. Total assets managed by the industry has decreased from Rs. 25.28 trillion in April 2019 to Rs.23.53 trillion in April 2020, which is a decrease of $6.91 \%$ in assets over that of April 2019.

2. The proportion of Equity oriented schemes in the total Indian Mutual Fund Assets has declined by $3.6 \%$ over April2019/2020 period, while the Exchange Traded Funds \& Fund of Funds has declined by $1.70 \%$ during the same period.

3. The total Assets of Individual investors has increased by Rs, 79,126 Cr., while that of Institutional investors decreased by Rs. $253,879 \mathrm{cr}$. during the period of April 2019 and April 2020. The recession and COVID-19 effect were more detrimental to Institution investors

All this suggest a huge outflow of money from the equity markets for both domestic and foreign investors. In this case, even a small percentage drop of just $6.91 \%$ has huge implications when the underlying assets are for thousands of crores.

Due to supply-chain disruption and heavy global dependency on China, new trade laws were signed. These have heavily changed the market economics due to the pandemic haltering import-export at a massive unprecedented scale. Fensom [15] impressed upon on how severely extended shutdowns in China or weaker-than-expected Chinese growth will affect the sectors which rely heavily on Chinese imports for the quarters to come. A thorough study asserted China is the 3rd largest partner contributing in the export and import trade of India. Any unfavorable influence on the Chinese industry will have rippling effects on the Indian economy. The study recommended that the government should take fiscal and monetary measures that involve motivating social spending by the public, lowering interest rates on loans, intervening in foreign exchange markets, lowering bank charges, providing short term credit for companies, suspension of payment of electricity bills, water bills and other govt charges, among others [18]. A lot of these have been done and can be contributed to the rapid recovery we are currently seeing in the market as of September 2020.

A contagion-focused study revealed that India should prepare for a health infrastructure crisis at present and an agonizing economic contraction in the near future if the government is unable to execute a proper policy framework [19]. After 3rd March 2020, we see this fall being proven true and being much more rapid than expected.

Thus, Indian markets haven't been spared the heavy massacre that the globe is seeing with halted consumer spending, manufacturing, commerce and import-exports at a massive unprecedented scale. Investor confidence in the market is very much dependent on the number of reported COVID-19 cases and fiscal policies being implemented by the government.

\section{Research Methodology}

This paper follows a descriptive research design by carrying out a systematic review of published papers and studies pertaining to the area of research on the current situation on papers published using the Google Scholar and Open Athens search engines to find high quality and relevant studies.

For analysis, inferences and numbers from several government and United Nations reports, or verified news articles were used. Other publishing journals and search engines like Ebsco, Jstor, Scopus, Frost \& Sullivan and Science Direct were also used.

Article based data was procured from relevant news websites and blog sites maintained by management consulting firms and data analytic companies. After a review of the studies, papers and documents listed in the literature review the key points of these studies have been reinstated along with personal findings and opinions to arrive at the conclusions and answers to the research objectives.

The data collected and used in this research project is descriptive and qualitative in nature. The data has not been processed through statistically heavy methods, rather it has been subjected to basic qualitative analysis restricted to a limited number of studies in lieu of the constantly changing information deluge on a daily basis about the market and economy. This study was conducted from July 30, 2020 to September 30, 2020. Total of 25 papers and articles were studied in depth. While past pandemics (From 1918 to 2020) and financial crashes have been discussed in multiple places, they have been done so in an extremely brief manner.

\section{Analysis}

\section{A. History of major pandemics}

1918 saw the rise in cases of 'The Spanish Flu' caused by the H1N1 influenza A virus, affecting around 500 million people around the globe and killing an estimated 20 million people more than the death toll of world war 1, after starting in small pockets in Europe, America and Asia. Prolonged quarantine measures and lack of business both domestic and internationally lead to an estimated global economic loss of at least 3 trillion USD. Accurate measures of economic losses and deaths are almost impossible to procure due to lack of accurate data. After a full year, it eventually vanished as the infected either died or developed an immunity.

1957 saw the rise in cases of 'The Asian Flu' caused by the H2N2 influenza A virus, originated in Guizhou, China that killed more than a million people worldwide. This affected the global economy negatively by around $2 \%$.

1968 saw the rise in cases of a similar pandemic, 'The Hongkong Flu' caused by the H3N2 influenza A virus, originated in China that killed more than four million people worldwide. This affected the global GDP negatively by a loss of $\$ 14.8$ billion USD. 
2002 saw the rise in cases of 'SARS' which again originated from Foshan-Guangdong, China with only 916 deaths via respiratory system breakdown but caused a massive drop to the global economy to the tune of $\$ 33$ billion USD.

2009 saw the rise in cases of 'H1N1 Swine Flu' originating from Mexico, which led to a $1.5 \%$ loss to the global economy and a loss of 284,00 human lives.

2013 saw the rise in cases of 'Ebola' which originated from Guinea, West Africa resulted in a loss of $\$ 2.2$ billion to the global economy and more than 11,00 deaths till 2015.

2020 has been ravaged by the current SARS-COV2 Covid19 pandemic and is estimated to make major economies lose 2.4 to $3.5 \%$ of their GDP i.e. at least a whopping $\$ 76.69$ billion USD.

Since the epicentre of this pandemic is China, how is it affecting China?

The major sources of trade of a country are its imports and exports. China is the 3rd largest partner contributing in the export (\$17 billion, 5\% total export) and import trade of India. Any undesirable influence on the Chinese industry will have drastic effects on the Indian economy.

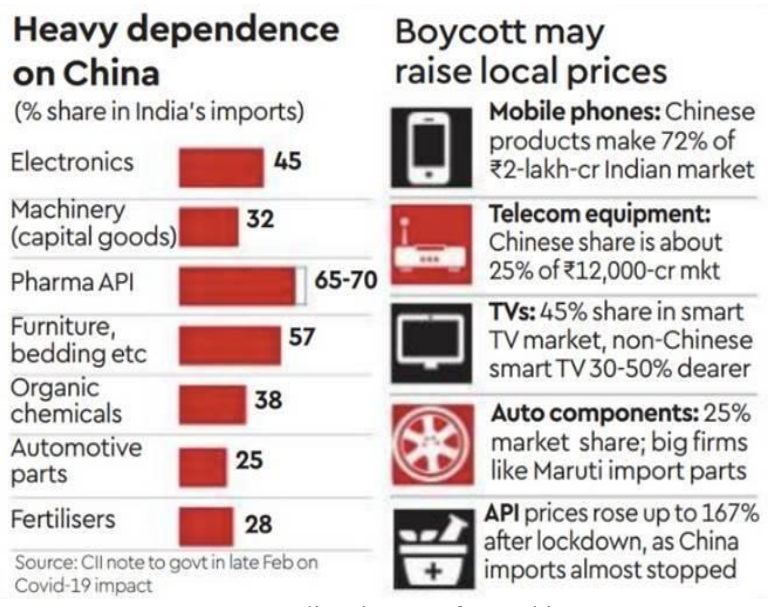

Fig. 5. India's imports from China

China is the market leader in trade, exporting worth $\$ 2,216$ billion followed by the USA with $\$ 1,553$ billion and Germany with $\$ 1,434$ billion as of January 2019. And yet with COVID19 , they managed to keep trade surplus for July-20 at $\$ 62.33$ billion, and a surplus of $\$ 46.42$ billion in June-20 with a $7.2 \%$ increase compared to last year.

Recently China's export performance has been boosted by record shipments of medical supplies and sustained demand for electronic products, has beaten many pessimistic estimates by global analysts. Even imports of industrial raw materials remained robust, with record imports of iron ore and copper, and a sharp jump in crude oil.

China's economy is gradually emerging from a record contraction in the first quarter but sustainability of this momentum is being questioned as rising coronavirus cases worldwide have severely affected demand. Chinese consumption has also subdued significantly amid job losses and very strict quarantine measures.

Exports are growing by double digits, and retail sales, which had been lagging for months, are back to pre-virus levels however, poorer households which form $60 \%$ of the economy are still struggling. Their current rebound is K-shaped, exacerbating widening income inequality, which was already a problem before the pandemic.

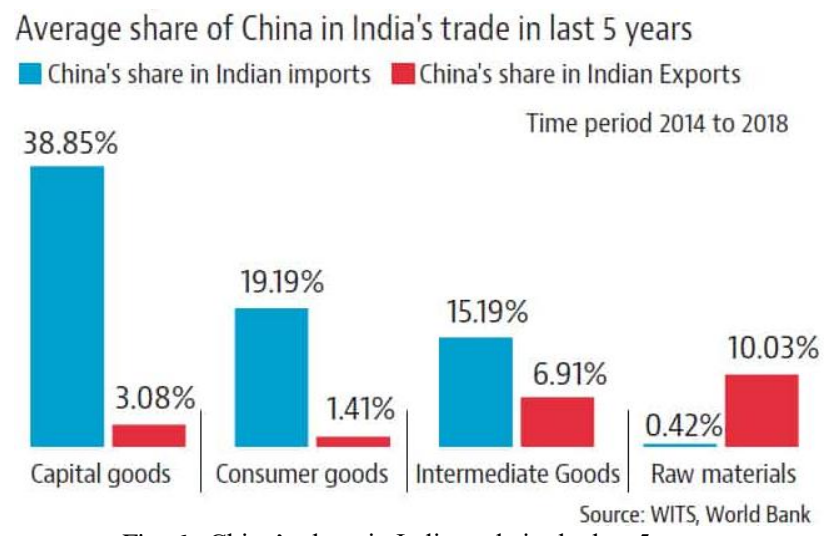

Fig. 6. China's share in India trade in the last 5 years

Government support around the world has been in the form of huge reforms to existing work structures and fiscal stimulus packages.

US launched four stimulus packages worth around \$2.7 trillion that involves small business loans, unemployment insurances, nutrition assistance, healthcare funding, government investment and bailouts of corporates, basic income of $\$ 1200$ for adults and $\$ 500$ per child.

Similar packages were launched in Canada which has allocated as much as $3 \%$ of its GDP with a $\$ 82$ billion from $\$ 500$ in credit features and tax deferrals to every Canadian getting at least CAD\$ 2000 for about 4 to 6 months of unemployment.

India announced a $\$ 22$ billion financial package that covers food for two-thirds of the population, increases basic income to farmers, senior citizens, self-help groups, women, medical insurance cover of Rs 5 million per healthcare worker covering more than 2 million people. Even injecting liquidity worth $\$ 85$ billion into the economy collateral free loans for MSMEs, repo rate reduction by 75 basis points, extended government contracts, liquidity infusion for NBFCs, utilities firms etc.

For India, Pre COVID-19, GDP growth slowed to $4.7 \%$ in 2019, the lowest level since 2013. Unemployment reached a 45year high. Industrial output from the 8 core sectors at 2019 end fell by $5.2 \%$-the worst in 14 years. Private sector investment had been stagnant for several years and declining in recent times and consumption expenditure had also been falling, for the first time in several decades. Urban consumption demand indicators show sales of passenger vehicles and consumer durables growth contracted in February 2020. Overall, urban consumption has stagnated in the fourth quarter. Rural consumption indicators 
like motorcycle sales and consumer non- durable segment remained in contraction in February 2020, reflecting weak rural demand. However, these metrics have recovered rapidly as of September-20.

India's core sector consisting of coal, crude oil, natural gas, refinery products, fertilizer, steel, cement, and electricity, output contracted $38.1 \%$ in the April, 2020. This core sector forms $40.27 \%$ of the index of industrial production. The core sector had expanded by $5.2 \%$ in the same period in 2019 while it shrank 9\% in the March, 2020. This is the biggest fall in the core sector data ever recorded.

Core sectors saw refinery production decline by $24 \%$, steel production declined by a massive $83 \%$ while electricity generation saw a decline of $22.8 \%$ from 2019 while crude oil production slipped $6.4 \%$. Coal production showed a decline of $15.5 \%$, cement production was a massive $86 \%$ fall from April, 2019.

Goldman Sachs Group Inc. expected gross domestic product to contract 5\% in the fiscal year through March 2021, which would be India's deepest recession ever; while ICRA expected it to be a steeper 9.5\%. Chief India economist at Barclays estimated growth declining to 2.5 per cent in 2020 , and 3.5 per cent in FY20-21 eventually leading to a loss in excess of $\$ 120$ billion from global and domestic trade revenues [6]. Bank of America Securities estimated India's GDP to contract 4-7.5\% if COVID-19 vaccine is delayed, as of July 13, 2020 [25].

India's real GDP depleted to its bottom in over six years during the fourth quarter of FY 2019-20. All these estimates were defeated when the official report recorded that India's GDP shrank 23.9\% year-on-year in the second quarter of 2020, much worse than the final market forecasts of an $18.3 \%$ drop. This is the biggest recorded economic contraction in India's history.

To create a snapshot of the contribution of different sectors of the GDP, the most important and the fastest growing sector of Indian economy were services. Trade, hotels, transport and communication. Financing, insurance, real estate and business services and community, social and personal services account for more than 60 percent of GDP. Agriculture, forestry and fishing constitute around 12 percent of the output, but employs more than 50 percent of the labor force. Manufacturing accounts for 15 percent of GDP, construction for another 8 percent and mining, quarrying, electricity, gas and water supply for the remaining 5 percent.

Construction (-50.3\%), hotels and transportation (-47\%) and manufacturing $(-39.3 \%)$ recorded the biggest plunges. Positively, farm sector grew $3.4 \%$. On the expenditure side, private spending shrank $26.7 \%$, inventories fell $20.8 \%$, exports plunged $19.8 \%$ and imports dropped a whopping $40.4 \%$. Only government consumption jumped $16.4 \%$ as it implemented country-wide relief measures via food and medical supply to help curb the impact of the pandemic.

2020 Indian stock market saw one of the most highly volatile markets ever, even beating the 2001 and 2008 financial crises.
The US market in mid-march 2020 noted the worst trading in the past 124 years. The Indian market also saw a $20 \%$ cut in benchmark indices making the Indian equity market enter the territory of Bear market. BSE Sensex witnessed a sharp fall in the stock market on March 23, 2020 due to the Coronavirus fear across the global market. The Sensex had fallen 3500 points to approx. 26, 000. On the other hand, the NSE Nifty fell 11 percent. The Indian market opened on a positive note with promising signals from the foreign markets only to fall flat with the foreign investors continuously withdrawing money from the Indian markets.

In 20-23 March of 2020 Sensex fell more than 4000 points and Nifty 500 fell around 1000 points. Compare that with current September 2020 market we see the market has undergone a U-shaped recovery wherein the US market plunge, fear of coronavirus, staggered opening of lockdowns in India and economic packages by government have been priced in by the market. Nifty 500 has risen from 6,243 on March 23 to 9326 as of September 30, 2020. As can be seen in figure 7, the 50day moving average as almost crossed over the 200-day moving average forming a 'golden cross' technical indicator signifying a possible rally in the short term unless some significantly negative news comes to light.

While BSE Sensex Index has recovered nearly 20\% since hitting a record low - a day before the nationwide lockdown started on March 25 - it is still down around $26 \%$ so far this year. That is despite $\$ 266$ billion of economic stimulus announced by the government and the aggressive liquidity measures and interest rate cuts by the Reserve Bank of India.

Market highlights for the Indian stock market as of July 2020 was as follows:

1. All banks and NBFCs missed estimates in lieu of contingent liabilities to cushion the blow from imminent large-scale corporate/retail defaults. Bajaj Finserv Ltd. had the steepest Net profit plunge of $77 \%$ to Rs 194 crore

2. Tech firms, the darlings of retail and non-HNIs posted disappointing earnings as lockdowns lead to payment delays and requests for discounts.

3. Reliance Industries Ltd., announced a profit decline of almost 40\% from 2019.

4. Bharti Airtel Ltd., that lost its position as India's No.1 to Jio of Reliance Industries. It reported a loss of 52.4 billion rupees ( $\$ 694$ million).

5. Materials stocks, especially cement companies like UltraTech Cement Ltd., had the largest gains. Health care and consumer staples were the only other sectors to record growth due to panic buying of FMCG and increased government funding to pharma companies.

Compare that with a strong recovery by the end of September 2020,

Nifty had gained $18 \%$ since June and around $50 \%$ since the 
lows of Mar-20. The fall towards the end of the month was due to rising tensions between China and India on the border, reports of a resurgence of Covid-19 waves in European countries and major credit rating agencies rating FY21 Indian GDP contraction to $\sim 11 \%$. Nonetheless, as in the preceding months, pharma, IT and consumer durables remained the major market movers gaining greater than $6 \%$ individually. IT sector especially is looking forward to leveraging the $\$ 2.4$ trillion dollar USA stimulus package to ramp up revenues. Banks however, were the biggest losers due to a US Treasury report listing a large number of Indian banks being involved in money laundering.
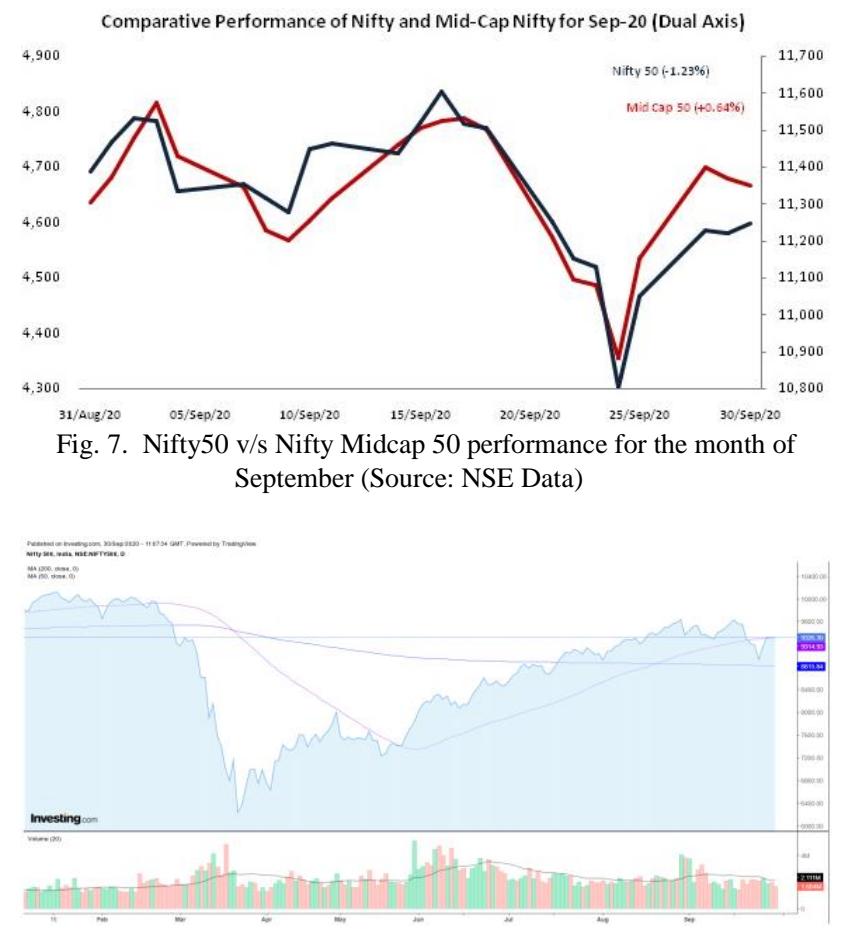

Fig. 8. 30 September 2020, Nifty 500 Chart depicting rapid recovery

Indian travel and tourism sector contributed nearly $6.8 \%$ of GDP i.e. $\$ 194$ billion, in 2019 down from $9.2 \%$ at $\$ 240$ billion in 2018 . This sector employs $8.1 \%$ of the total employment in the country and has suffered the hardest due to Covid-19. Disruptions in the tourism sector will render many people in unemployed since the tourism sector also has linkages to other sectors like agriculture, transport, handloom, and FMCG to name a few. The food and hospitality sector are under severe pressure from high fixed costs and minimal footfalls after months of zero business when the lockdown started in March 2020. The federation of associations of the tourism and hospitality industry has put forth a loss projection of about Rs. 100 billion for the industry for just the remainder of 2020. This fall in number of tourists translates into a drastic fall in foreign exchange earnings of approximately Rs. 2,10, 981 crores in the first three quarters of FY 2019.

Resurgence in covid-19 waves in several countries, constantly rising cases globally, Russia-Saudi Arabia price war that plunged prices to a 17-year low in March, reduced fuel requirements due to quarantine affected travel and business has been a blessing in disguise for countries like India who import oil. India itself imports $82 \%$ of its oil needs and aims to bring that down to $67 \%$ by 2022 . Current ideas for this are by replacing it with local exploration, renewable energy and indigenous ethanol fuel

Impact of Government policies and economic packages is being seen in the recovery of stock markets to some extent lately and improvement in the demand-supply situation. Better corporate profit reporting, improved performance of MSME \& strategic sectors, good agriculture output due to a normal monsoon, pent up demand and rural migration would support the strengthening of the economy indicated by higher agricultural and consumer staples spending since March compared to February.

\section{B. Case Study: India's economic recovery with focus on consumption}

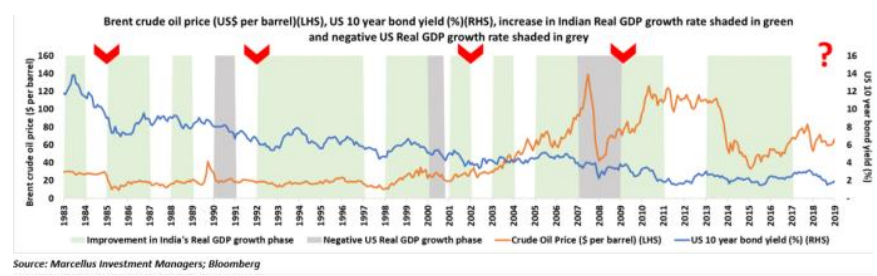

Fig. 9. Indian economic boom is always preceded by USA recession

From historical data, we can infer that in the last four decades, every single economic recovery in India has been preceded by a US recession, falling US Bond Yields and a drop in oil prices due to lower usage from the world's top-most oil consumer i.e. USA. With Brent crude having corrected from US $\$ 84 /$ barrel to US $\$ 41 /$ barrel now, US Treasury yields below zero and with the US economy now likely to be in recession, currently all three conditions for an Indian economic recovery.

Why has this been the case?

1. Cheap money

Long gone are the days of real estate being considered the only credible asset for masses of Indian households to invest in. Since 2015 from real estate there has been a noticeable shift in the portfolio of average Indian investors into financial markets leveraged by easy to use zero commission brokerages like Zerodha, Upstox and Groww to invest into the stock market and mutual funds. Unfortunately, parallelly Indian lenders have seen a reduced savings rate of Indian's from their income down from $25 \%$ to $17 \%$ and hence these banks happily provide debt financing and risk capital is left at the mercy of foreign investments a majority of it coming from the USA when their bond rates fall and US investors take out money to invest into foreign markets in hopes of generating higher returns.

The data from the 2003-07 boom of India and China suggests a direct relation with the massive drop in the US 10-year bond yield from a very respectable $6.7 \%$ in Jan 2000 to $3.4 \%$ in June 
2000 ensuring pumping heavy foreign investment into Indian and Chinese markets. This happens at a global scale beyond just USA since USA treasury bills are considered to the global standard for risk-free asset and when debt returns fall, investors pull money out to invest into equity. A similar scenario took place during the 2009-10 boom of India and its multitude of IPOs and QIPs that was preceded by the Lehman Brothers induced global markets massacre.

\section{Cheap Oil}

When the largest consumer of oil i.e. USA goes into recession, the price of oil falls down. Brent crude has fallen from $\$ 88$ per barrel to $\$ 41$ in September 2020. As per 2018, India depends on oil imports for $82.8 \%$ of its oil requirement, adding up to about $30 \%$ of total imports. This figure has not changed enough. A one-dollar fall in its price saves India around USD 1.5 billion per annum and reduce the cost of subsidies that help sustain the domestic prices of oil products like LPG and Kerosene. It thus has a severe positive impact on reducing Current Account Deficit and Fiscal Deficit of India and may also help reduce retail inflation (CPI) as evidence from historical data suggests.

Historical data suggests that consumption recovers sharply after economic crises.

Post the Spanish Flu Pandemic of 1918-20, consumption rapidly recovered to its pre-pandemic levels within 3 years by 1923 and also went ahead to grow consistently at 3\% per annum in real terms from 1921 until 1929 for America and Europe.

During World War II, US consumption saw a plunge of $2 \%$ per annum. However, since 1945 till 1955, for the decade there was a rise in consumption at $3 \%$ per annum. This pattern of consumption (fall during the war and recovery post-war) was as true for Europe and other major economies as well.

Durable goods consumption gained pace after the 2009 crisis, growing at a healthy $1 \%$ per annum in real terms compared to the previously laggard $0.5 \%$.

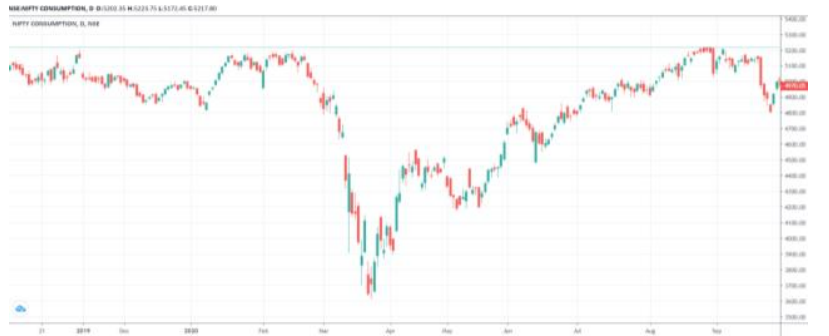

Fig. 10. markets closed above pre-covid19 high from February, in less than 6 months by August end

The Permanent Income Hypothesis (PIH) was postulated in 1957 by Milton Friedman, stated that the level of consumption of an average consumer catches up rapidly once the crisis subsides due to humans being "forward-thinkers", provided their perceived average future income hasn't wavered significantly. Across the world, rapid recovery seen in consumption across countries as diverse as China, the US, and India through the summer and into the fall season, validates Friedman's PIH. Just like consumers, the stock market too looks forward and discounts the future rather than being stuck in past market movements. Consumer segment being what the name states, consumption most of it staple, some proprietary, thus has historically always seen a quick rebound and consistent growth over the long term. This theory thus stands as proof on why a longer-term view should be considered when evaluating the stock market.

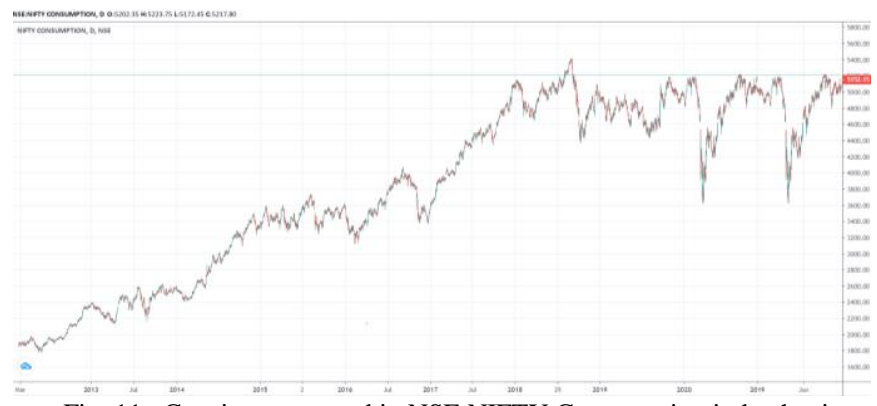

Fig. 11. Consistent uptrend in NSE NIFTY Consumption index having slowed down only in the last 3 years

India is arguably the only economy in the world, where most industries have a monopoly or duopoly with market control of greater than $80 \%$ and also a similar figure for the total revenue generated from the entire industry. Be it Pidilite and Adhesives, Asian Paints and Berger for Paints, Adani and Marico for Oils and Nestle for FMCG and Baby Milk Powder, all these massive companies control $80 \%$ of the market and have tremendous barriers to entry and low working capital cycle. This translates into them consolidating their multi-billion-dollar market share and reducing competition further especially during crises due to favorable free cash to reinvest into core business and fight out a very temporary slack in sale volumes. Thus, the market foresees this correction and rewards investors accordingly once it eventually adjusts its prices to reflect the strong confidence in the unflinching consumption market of 132 Crore Indians for the years to come. Especially for those invested in the consumption industry monopolies.

\section{Conclusion}

A mid-2020 United Nations report from their department of Economic and Social Affairs expects COVID-19 to slash global economic output by a whopping $\$ 8.5$ trillion over the next 2 years erasing out progress made in the last 4 years. The global economy is projected to contract sharply by $3.2-5 \%$ this year. This will push a large number of people into extreme poverty almost an estimated 34 million people, in 2020 with $56 \%$ of this increase occurring in African countries. Estimates suggest an additional 130 million people may fall into extreme poverty by 2030 , setting us back by almost a full decade on our efforts to eradicate extreme poverty. 
This pandemic is disproportionately harming those sections of the society which fall under the low-skilled, low-wage jobs category while leaving higher-skilled jobs somewhat minimally affected or rather affected for a very short term. This translates into further widening the income inequality both within countries and between countries.

Especially in India where about $69 \%$ of the 138-crore population is poor and living at a horrendous, just $\$ 2$ and below daily. An increase of even $1 \%$ in this metric means millions more Indian's now lose access to basic healthcare, education and food and mortality rates especially infant mortality rates skyrocket according to the same UN report.

Most of the developing economies around the globe, weighed down with large amounts of public debt are struggling to implement sufficiently large economic packages and other much-needed stimulus measures. Developing economies and sustainability of their debt is rapidly being destabilized by the falling exports, particularly the ones that are commodities, tourism revenues or remittances driven. It is vital to ensure that these developing economies have rapid access to international funds to deal with current liquidity shortages and trade imbalances. Along with these short-term measures, most of these economies will need extensive debt restructuring to have enough fiscal bandwidth necessary to stimulate growth and recovery.

Some sectoral recommendations beyond tax benefits include:

Telecom: Upgrade existing infrastructure to implement new technologies like 5G and Augmented Reality to help healthcare professionals and service sector as a whole. Reduce TRAI fees short-term and improve regulations long-term.

Auto: Deferred payment system for dynamic interest loans both on consumer and manufacturing end.

Consumer Retail: Laxing import and manufacturing of rules for essential goods. Cover up this loss by imposing a higher tax on luxury retail goods for the short term.

Aviation and Tourism: Significantly reduce Air Turbine Fuel (ATF) costs by reforming existing tax laws and upgrade MROANS facilities to make them safer and more efficient.

Power \& Transport: Deferred billing, using this time of low traffic for up-gradation and digitization using the latest technology to reduce cost on a countrywide scale.

Agriculture: New food bills have already been passed to connect farmers and consumers directly by removing the necessity of using APMC middlemen, ensure corporations do not misuse and hoard food due to removal of corporate produce storage cap and improve the digital infrastructure to connect 17 crore farmers big and small to buyers and ensure they get the correct prices for the product even with the removal of minimum support price.

Indian agri-business economy has shown remarkable resilience largely favored by an excellent monsoon season this year.

Where will the government find the funding for these nationwide infrastructure developments and regulator reforms?
This is where the saving from the cheap oil kick in. Previously discussed was the $\$ 1.5$ billion India saves for every dollar the price of oil goes down. The current 20-30-dollar drop means that India is saving around $1.1 \%$ to $1.6 \%$ of its nominal GDP which can be deployed strategically to improve and consolidate India's current infrastructure and regulations. With the rise of globalization, free trade and internet the number of Indian in 2019 saw the addition of 3 new billionaires a month according to Hurun Global Rich List 2020. Tax reforms to charge a higher tax on these individuals and goods like cigarettes and alcohol can be a very simplistic solution to think of, the actual feasibility of implementation, however, will be ten times more challenging. This, and taking steps to curb corruption are nonetheless a tried and tested place to start looking for solutions to increase government revenue.

This pandemic has revealed many weaknesses in the global system. Despite India's accumulated experience in crisis management, we have had to isolate ourselves in our homes bringing usual levels of trade and commerce to a standstill.

From massive losses to individual sectors especially media, realty, hospitality, service sectors and manufacturing to an excellent rapid recovery, we see a complete market upheaval. The economy as a whole has a long way to go especially when important segments of economy like the mutual fund industry, foreign investment and domestic or international trade are yet to reach pre-COVID-19 levels.

As of September 30,2020 India, has reported 6.31 million cases with reportedly 98,708 deaths. Recently the last weeks of September saw the country increase its reported positive cases by $\sim 85,000$ every day showing how fast it is spreading making India the second-worst affected country after the USA with 7.45 million cases. India needs to adopt significant measures of quarantining as it did in March - April but has since been watered down to normal almost no lockdown state to start commerce from a standstill to at least something.

Indian agri-business economy has shown remarkable resilience largely favored by an excellent monsoon season this year.

Strategic fiscal packages to support small business, farmers, frontline workers like police, border forces and healthcare professionals need to be continually supported. Such packages also need to be provided to big corporates such that they can support the large amounts of people they employ since as we know unemployment levels are currently at a 45 -year high. Opportunities for lucrative foreign investments also need to be made to jumpstart the declining trend of FDI in India and accelerate growth in large scale industrialization, infrastructure and digitization of India.

The current time should be utilized to the maximum to upgrade our infrastructure, introduce new technologies to improve current pipelines of all existing industries and ensure the poor and marginal citizens who are disproportionately affected in this pandemic to the point of dying, receive sufficient support during and after this pandemic. 


\section{Limitations and Scope for Further Research:}

The results from this paper cannot be generalized for all the other economies since it's a generalized commentary on India's situation and responses.

The findings are based on current data till September 2020 and hence will change over the course of each succeeding month due to the dynamic nature of market data and fiscalmonetary and socio-economic policies.

Further study has been done in other papers reviewed that undertook changes in market prices of sectoral indices of India during the pandemic-panic months from Jan to April and similar study can be done for the succeeding months of market recovery aided by minimal panic due to reduced media coverage and declining positive cases being reported from taking preventive steps nationally to curb the spread.

\section{References}

[1] Akriti Gupta, D. G. (2019, 12). Foreign Institutional Investments in India: A Trend Analysis. Our Heritage, 67(10).

[2] Al-Awadhi, A. A. A, "Death and contagious infectious diseases: Impact of the COVID-19 virus on stock market returns," J Behav Exp Finance, 2020.

[3] Alok Kumar Mishra, B. N. (2020). Does Indian financial market nosedive by COVID-19 outbreak in comparison to post-implementation of demonetisation and GST? Asia-Pacific Applied Economics Association, WORKING PAPER SERIES(WP/AP/2020-01).

[4] Aravind M, M. C. (2020). COVID 19: Effect on leading pharmaceutical stocks listed with NSE. International Journal of Research in Pharmaceutical Sciences.

[5] Ashraf, B. N. (2020). Stock markets' reaction to COVID-19: Cases or fatalities? Research in International Business and Finance.

[6] Bajoria, R. (2020, 4 7). No economic activity will cost India $\$ 120$ billion. Rediff.com Business.

https://www.rediff.com/business/interview/coronavirus-in-india-noeconomic-activity-will-cost-india-120-billion/20200407.htm

[7] Bhagavatula Aruna, A. H. (2020). Impact of COVID 19 Virus Cases and Sources of Oil Price Shock on Indian Stock Returns. Structural VAR Approach. IAEE Energy Forum (Covid-19 2020).

[8] Bloomberg. (2020, 64). Covid-19 impact: Nifty50 scorecard shows worst profit slump in 6 years. Business Standard.

https://www.business-standard.com/article/markets/covid-19-impactnifty50-scorecard-shows-worst-profit-slump-in-6-years120060401711_1.html

[9] Bowes, D. R. (2018). Stock Market Volatility And Presidential Election Uncertainty: Evidence From Political Futures Markets. The Journal of Applied Business Research, 34(1).

[10] Deepmala Jasuja, D. P. (2020, 1). Anticipation of Consequences \& Sectoral Impact of COVID19- An Indian Outlook. SSRN Electronic Journal.
[11] Kishore Kumar Das, S. P. (2020, 5). The impact of Covid-19 in Indian economy - An empirical study. International Journal of Electrical Engineering and Technology (IJEET), 11(3).

[12] Manish Sharma, D. V. (2020, 4 18). COVID -19 and Economic Shocks: An Analysis in. Mainstream Weekly, LVIII(18).

[13] Rao, D. D. (2020). Emerging Challenges and Strategic Implications for Indian Mutual Fund Industry in Post Covid -19

[14] Regime. SSRN Electronic Journal.

[15] S. Gunaseelan, D. N. (2020). Business and economic recessions in India during the Covid-19 - A Review. Journal of Xi'an University of Architecture \& Technology.

[16] Fensom, A. (2020, 2 18). Coronavirus Deepens India's Economic Chill. The Diplomat. https://thediplomat.com/2020/02/coronavirus-deepens-indias-economicchill/

[17] Goyal, A. (2020, 4). Post Covid-19: Recovering and Sustaining India's Growth. Indira Gandhi Institute of Development Research, Mumbai.

[18] Jain, D. (2020). COVID 19 Pandemic: Media Coverage \& Panic Induced Uncertainty In Indian Stock Market And Sectoral Returns. International Conference On Innovation Perspectives, Psychology And Social Studies.

[19] Kamakshi Mehta, S. S. (2020). COVID-19 : A nightmare for the Indian Economy, 31(20)

[20] Manish Kumar Singh, Y. N. (2020). Contagion effect of COVID-19 outbreak: Another recipe for disaster on Indian economy. J Public Aff.

[21] Moyuru Baba, K. M. (2020, 2 16). India's house of cards: big pile of risky debt lurks below. Nikkei Asian Review. https://asia.nikkei.com/Spotlight/Datawatch/India-s-house-of-cards-bigpile-of-risky-debt-lurks-below

[22] Papadamou, S. a. (2020). Direct and Indirect Effects of COVID-19 Pandemic on Implied Stock Market Volatility: Evidence from Panel Data Analysis. Munich Personal RePEc Archive.

[23] S. Mahendra Dev, R. S. (2020). Covid-19: Impact on the Indian Economy. Indira Gandhi Institute of Development Research, Mumbai.

[24] Sabharwal, S. (2020, 7). Tweet Buster: Risk of blindly chasing multibaggers; smart \& dumb money. The Economic Times. https://economictimes.indiatimes.com/markets/stocks/news/tweetbuster-smart-money-dumb-money-and-when-not-taking-risks-is-thebiggest-risk-of-all/articleshow/77048313.cms?from=mdr

[25] Sapkota, S. \&. (2020). Impact of Epidemic Infectious Disease and Death on Stock Return: Evidences from Asian Stock Markets with COVID-19. SSRN Electronic Journal.

[26] Securities, B. o. (2020, 7 13). India's GDP to contract $7.5 \%$ if Covid vaccine is delayed, $4 \%$ in base case: Bank of America Securities. The Economic Times.

https://economictimes.indiatimes.com/news/economy/indicators/indiasgdp-to-contract-7-5-if-covid-vaccine-is-delayed-4-in-base-case-bank-ofamerica-securities/articleshow/76936888.cms

[27] Somvanshi, K. K. (2020, 6 11). Five trends that are likely to play out for the FMCG sector due to Covid. The Economic Times. https://economictimes.indiatimes.com/markets/stocks/news/five-trendsthat-are-likely-to-play-out-for-the-fmcg-sector-due-tocovid/articleshow/76321451.cms

[28] Wood, C. (2020, 4 13). Chaotic shutdown in India makes FII sentiment more bearish: Christopher Wood. The Economic TImes. https://economictimes.indiatimes.com/markets/expert-view/chaoticshutdown-in-india-makes-fii-sentiment-more-bearish-christopherwood/articleshow/75117742.cms 